\title{
AMYLOIDOSIS IN ANKYLOSING SPONDYLITIS
}

\author{
BY \\ KAI ENNEVAARA AND MARTTI OKA \\ From the Rheumatism Foundation Hospital, Heinola, Finland
}

Amyloid disease is rare as a complication of ankylosing spondylitis. The autopsies of Teilum and Lindahl (1954) included two such cases but no clinical details were given. A third case, in which the final histological diagnosis was also made at autopsy, was reported by Halford and Clark (1957).

The aim of this paper is to report three cases of ankylosing spondylitis in which the presence of amyloidosis was diagnosed clinically and confirmed by renal or rectal biopsy.

\section{Case Reports}

Case 1, a labourer aged 38, had no rheumatic diseases in the family, and his previous health had been good except for a transient frequency of urination.

The first symptoms of the present illness appeared in 1943 when the patient was on active service. Both hips became painful and he was treated in a military hospital for 3 months in 1944. At this time he also had low back pain and symptoms in the right knee. He was then almost symptom free from 1944 to 1947, but persistent back symptoms suddenly began in 1947 in the lumbar region, and the disease has since run a slowly progressive course affecting the whole spinal column, shoulders, hips, and right knee. Since 1954 the patient has been unable to work. $X$-ray therapy to the spine and hips was given in 1956.

The patient was admitted to the Rheumatism Foundation Hospital on April 11, 1962. His general condition was poor. Physical examination of the heart and other viscera did not reveal any abnormality, but pitting oedema was observed in the feet.

Joints.-Movement of the cervical spine was greatly limited, and the thoracic and lumbar spine were totally ankylosed. The fingertips remained $30 \mathrm{~cm}$. from the floor and Schober's sign was positive $(0.5 \mathrm{~cm}$.). The thoracic spine was markedly kyphotic with scoliosis to the right. The shoulder joints and hips were painful and hydrops appeared in the right knee.

Radiological Findings.-Bamboo formation was beginning in the cervical spine and marked bamboo formation

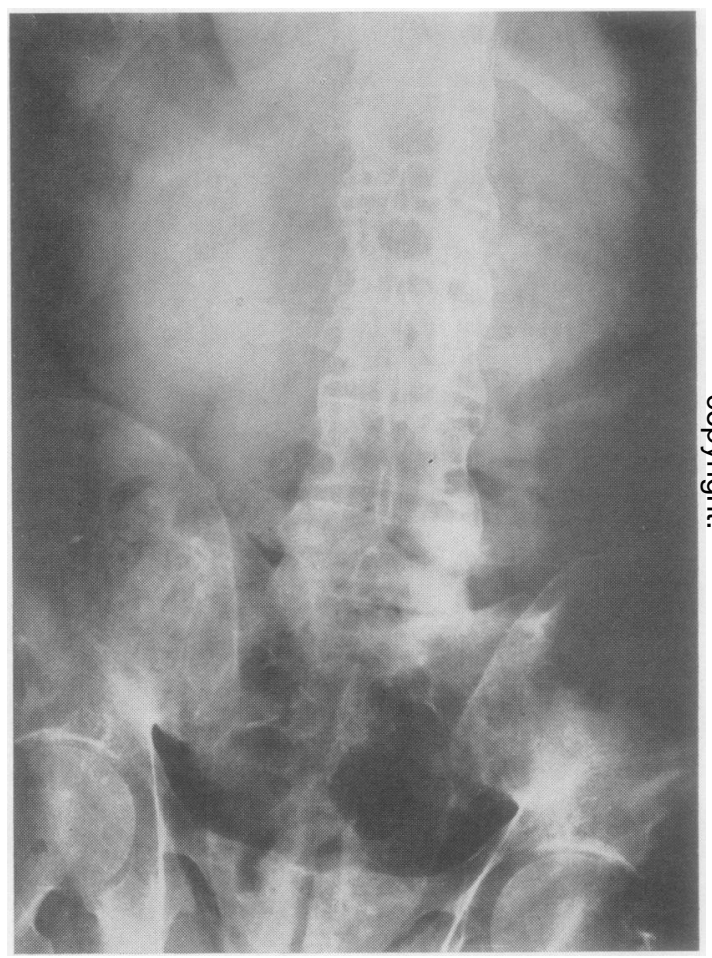

Fig. 1.-Case 1. $X$ ray showing bamboo spine in lumbar region. The sacro-iliac joints are narrowed and eroded with slight marginal sclerosis.

in the thoracic and lumbar spine (Fig. 1); the sacro-iliac joints were fused. The shoulder joints showed erosions. In the hips, knees, hands, and feet the $x$ rays were normal.

Laboratory Findings: E.S.R. $101 \mathrm{~mm} . / \mathrm{hr}$; haemoglobin $13.3 \mathrm{~g} . / 100 \mathrm{ml}$; Waaler-Rose titre 0 ; latex negative; antistreptolysin titre (AST) 20; C-reactive protein (CRP) $+7 \mathrm{~mm}$.; serum uric acid $4.2 \mathrm{mg}$./ $100 \mathrm{ml}$., serum cholesterol $366 \mathrm{mg} . / 100 \mathrm{ml}$. 
Electrophoresis: albumin 10.9 per cent., $\alpha-1$ globulin 3.6 per cent., $\alpha-2$ globulin 55.3 per cent, $\beta$ globulin 16.6 per cent., $\gamma$ globulin 13.6 per cent. Total protein $4 \cdot 8$ per cent. with an albumin/globulin ratio of $0 \cdot 12$.

In the hospital the patient had continuous proteinuria varying from 3.8 to 13 per thousand. The urinary sediment contained hyaline and granular casts; the cell count was normal and Gram's stain negative. Serum creatinine was $0.8 \mathrm{mg} . / 100 \mathrm{ml}$, , creatinine clearance $127 \mathrm{ml}$./min. The specific gravity of the morning urine gave values up to $1 \cdot 022$. A congo red test was not performed.

Renal Biopsy (Fig. 2).-The glomeruli were in part homogenized and absorbed congo red. The tubules were enlarged, the epithelium was granular and vacuolized, and the basement membrane contained amyloid. Some blood vessels also showed slight amyloid deposits.

Comment.-In a 38-year-old man with 19 years' history of back pain and simultaneous symptoms in a few large peripheral joints, roentgenography revealed a characteristic bamboo spine. The disease had markedly lowered his general condition, the erythrocyte sedimentation rate was very high, and serological tests for rheumatoid disease were negative.

The disease was complicated by proteinuria, hypoalbuminaemia, and amyloidosis, the last being confirmed by renal biopsy.

Case 2, a farmer aged 52, had had two brothers die of pulmonary tuberculosis. There were no rheumatic diseases in the family. The previous health of the patient had been good.

The first symptoms of the present illness appeared in
April, 1961, as pains in the chest muscles and back. He was admitted to a central hospital because of his periods of fever and anaemia in February, 1962. While in hospital the patient had three attacks of paroxysmal tachycardia. Peripheral joint symptoms suddenly appeared and have persisted since this date.

The patient was admitted to the Rheumatism Foundation Hospital on June 5, 1962. His general condition was still poor, the second heart sound was accentuated at the base, the blood pressure was $205 / 130 \mathrm{~mm}$. $\mathrm{Hg}$. The electrocardiogram was within normal limits. The tendon reflexes were exaggerated. The blood pressure later became normal after a period of rest in bed.

Joints.-These were characterized by unusual painfulness and stiffness, and the patient was bedridden. Objective signs were found in the shoulders, right elbow, right wrist, right fingers, knees (hydrops in the right), hips, and feet. The cervical and lumbar spine were painful with limited mobility. Lasegue was positive ( $60^{\circ}$ on both sides).

'After 2 months' hospitalization the patient became feverish (temperature $a d 8^{\circ} \mathrm{C}$.). This lasted for 4 months, and simultaneously the joint symptoms were very active; pain and stiffness appeared in nearly all joints and the whole spine. Several kinds of therapy were tried (steroids, phenylbutazone, antimalarials, corticotrophin) without noticeable success. However, a slow and slight remission set in and the patient was walking with crutches when discharged on February 20, 1963.

Laboratory Findings.-On admission the E.S.R. was $90 \mathrm{~mm}$./hr (maximum $136 \mathrm{~mm}$.); haemoglobin $12 \cdot 2$ g./100 ml.; Waaler-Rose titre 0; latex negative; antistreptolysin titre 40 ; L.E. cells negative; nucleic acid

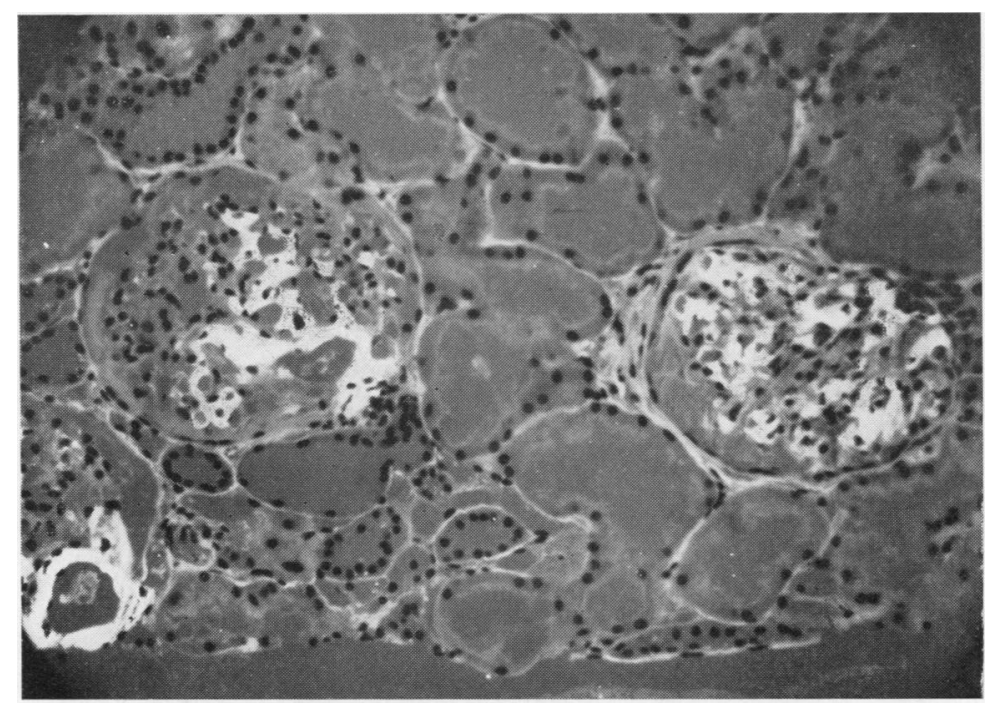

Fig.:-2.-Renal cortex of Case 1, showing amyloid deposits in glomeruli, the basement membrane of the tubuli and blood vessels. 
antibodies negative; C-reactive protein $+3 \mathrm{~mm}$.; serum uric acid $4.5 \mathrm{mg} . / 100 \mathrm{ml}$.; urine normal, no protein.

In January, 1963, protein was discovered in the urine (up to 4.5 per thousand) for the first time. The sediment contained hyaline casts, the cell count was normal, and Gram's stain was negative. Serum creatinine was $0.8 \mathrm{mg} . / 100 \mathrm{ml}$. and creatinine clearance $65 \mathrm{ml} . / \mathrm{min}$., and the specific gravity of the morning urine gave values up to $1 \cdot 025$.

Electrophoresis showed albumin 34.6 per cent., $\alpha_{1}$ globulin 5 per cent., $\alpha_{2}$ globulin $14 \cdot 1$ per cent., $\beta$ globulin 15.7 per cent., $\gamma$ globulin 30.6 per cent., total protein 6.9 per cent., albumin/globulin ratio 0.53 .

Serological tests were repeatedly negative. A congo red test was not performed.

Radiological Findings.-Syndesmophytes occurred in the lower part of the thoracic spine and in the lumbar spine (Fig. 3). The sacro-iliac joints were partly fused, with sclerosis on the right side.

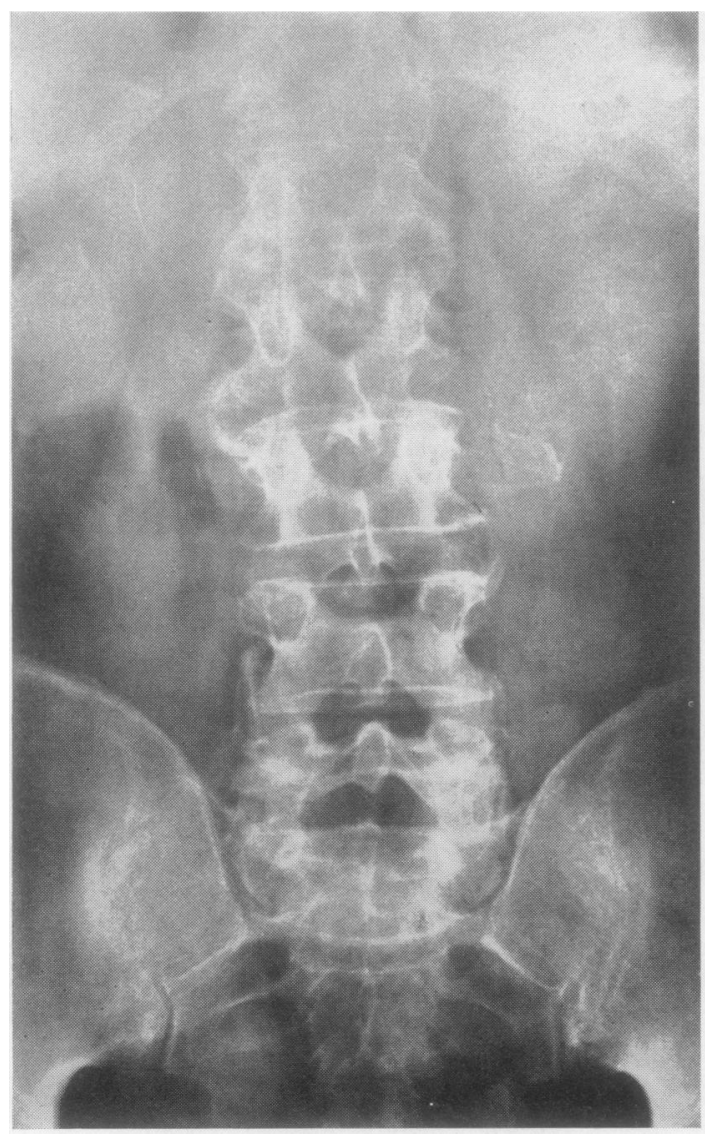

Fig. 3.-Case 2. $X$ ray showing syndesmophytes in the lumbar spine. The sacro-iliac joints are narrowed, irregular, and sclerotic.
Para-articular osteoporosis was found in the hands, destruction of cartilage in the left wrist, osteoporosis in the left knee and metatarsophalangeal joints, hallux $\bar{\omega}$. valgus in both feet, and hammer toes on the right foot.

Intravenous urography showed kidneys of normal size with spasm in the left pelvis and calices.

Rectal Biopsy.-Numerous plasma cells were found in the mucous membrane (Fig. 4).

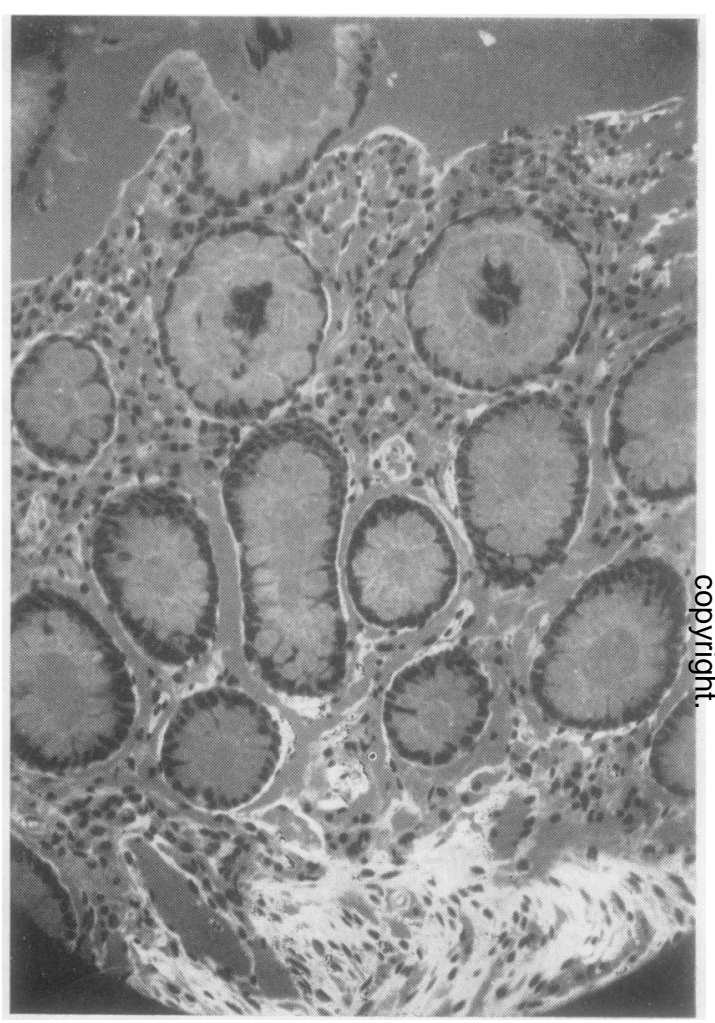

Fig. 4.- Rectal mucosa of Case 2, showing a homogenized basement membrane absorbing congo red. Amyloid also appears to a slighter degree in the stroma and capillary walls.

The basement membrane was fragmented and homogenized absorbing congo red. Amyloid was also found to a slighter degree in other parts of the stroma and the capillary walls.

Comment.-This 52-year-old male had a very severe, rapidly progressing, systemic disease affecting the spinal column and a great number of peripheral joints, with extreme pain and stiffness. The E.S.R. was very high but serological tests were negative.

A diagnosis of ankylosing spondylitis was established by typical radiological findings: syndesmophytes in the thoracic and lumbar spine and sacro-iliac involvement.

The disease was complicated by proteinuria (only 
1 year 9 months after the first symptoms), hypoalbuminaemia, and amyloidosis, the last being confirmed by rectal biopsy.

Case 3, a farmer's son aged 24, had hepatitis at the age of 8. There was no record of any special disease in the family.

The present illness began in 1955 with peripheral joint symptoms after a period of low-grade fever. The patient was examined at the Rheumatism Foundation Hospital in September, 1955. Objective signs were observed in the right knee and left elbow; the E.S.R. was $36 \mathrm{~mm}$./hr; there was no protein in the urine. After this there was a symptomless period until 1959, when symptoms gradually appeared in several large peripheral joints and the spinal column. The patient was admitted to hospital in December, 1959. His general condition was poor (weight loss $13 \mathrm{~kg}$.); E.S.R. $100 \mathrm{~mm} . / \mathrm{hr}$; haemoglobin $10.5 \mathrm{~g} . / 100 \mathrm{ml}$; bentonite test negative; L.E. cells negative; granular casts in the urine but no protein. The cervical spine was painful, and some stiffness was observed in the whole column. Schober's sign was positive $(4 \mathrm{~cm}$.), and the chest expansion diminished $(4.5 \mathrm{~cm}$.).

Objective signs (limited movement and swelling) occurred in the shoulders, elbows, wrists, right hip, and knees. Muscular atrophy in the extremities was marked. Radiological examination showed involvement of the sacro-iliac joints, with pearlband-like changes (erosions and sclerosis), and slight osteoporosis in the hands and knees.

The patient was given small doses of steroid (prednisolone 5 to $10 \mathrm{mg}$./day) and phenylbutazone. After 3 months' hospital treatment, proteinuria was discovered for the first time, and the patient had symptoms pointing to an irritable colon (spasticity in colography). Intravenous urography showed no abnormality. The urinating protein was 3.9 per thousand, and total protein $4 \cdot 4$ per cent. Removal of congo red disappeared from serum 59.4 per cent. after $1 \mathrm{hr}$.

He was again admitted to the Rheumatism Foundation Hospital in February, 1962, when his general condition was poor, and pitting oedema was observed in the legs.

Physical Examination.-The visceral organs showed nothing abnormal. The blood pressure was $105 / 85$ $\mathrm{mm}$. Hg. The back was somewhat stiff. The fingertips remained $20 \mathrm{~cm}$. from the floor, the chest expansion was restricted $(3 \mathrm{~cm}$.), the Lasegue test was positive. Peripheral joint symptoms were found in the shoulders (pain), knees (hydrops and pain), and hips (pain, limited movement).

Radiological Findings (Fig. 5).--There was destruction of the sacro-iliac joints, and cartilaginous and bony destruction in the hips. The knees, hands, and feet were normal.

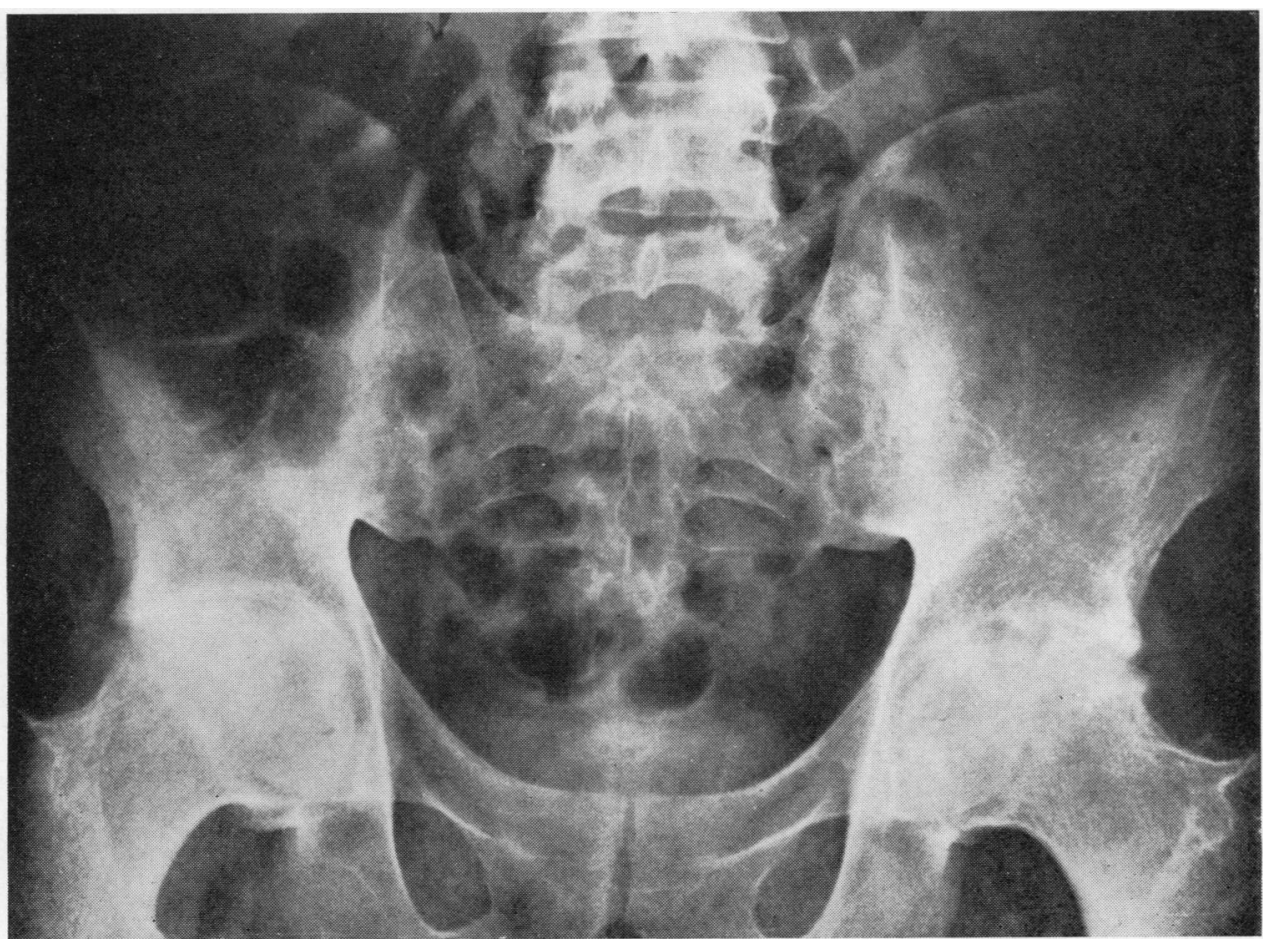

Fig. 5.-Case 3. $X$ ray showing ankylosis of sacro-iliac joints, destruction of the cartilages and spotty osteoporosis in both hip joints, and bony erosions in the left femoral head. 
Laboratory Findings.-E.S.R. $110 \mathrm{~mm} . / \mathrm{hr}$; haemoglobin 14.2 g. $/ 100 \mathrm{ml}$; Waaler-Rose titre 0 ; latex test negative; L.E. cells negative; antistreptolysin titre 40; C-reactive protein $+1 \mathrm{~mm}$; serum uric acid $7.5 \mathrm{mg} . / 100 \mathrm{ml}$; nucleic acid antibodies negative. Electrophoresis: albumin 31.4 per cent., $\alpha-1$ globulin 5.3 per cent., $\alpha-2$ globulin 20 per cent., $\beta$ globulin 20.6 per cent., $\gamma$ globulin 22.7 per cent., total protein 5 per cent., albumin/globulin ratio 0.46 . Serum cholesterol $497 \mathrm{mg} . / 100 \mathrm{ml}$. Urinary sediment: protein 17 per thousand, numerous erythrocytes, hyaline and granular casts. Serum creatinine $0.9 \mathrm{mg} . / 100 \mathrm{ml}$; creatinine clearance $105 \mathrm{ml} . / \mathrm{min}$.; removal of congo red from serum 66.2 per cent. after $1 \mathrm{hr}$. Specific gravity of morning urine $1 \cdot 025$.

Renal Biopsy (Fig. 6).-All the glomeruli were more or less obliterated by amyloid. Slight amyloid degeneration had occurred in the walls of the small blood vessels. Severe changes were found in the tubular system: peritubular fibrosis, tubular enlargement, and epithelial degeneration.

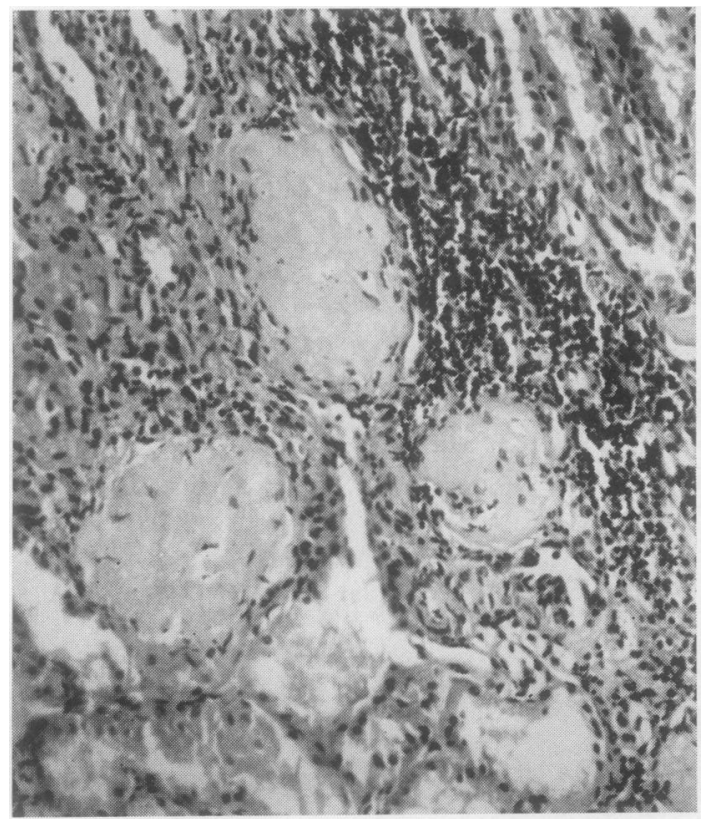

Fig. 6.-Renal cortex of Case 3, showing glomeruli obliterated by amyloid deposits.

A rectal biopsy showed definite amyloidosis of the mucosa.

Comment.-This 24-year-old male had a 7 years' history of severe systemic disease affecting a few large peripheral joints and the spine. The erythrocyte sedimentation rate was very high. The diagnosis of ankylosing spondylitis was based on the finding of far-advanced destruction of the sacro-iliac joints, typical physical signs, and negative serological tests.
The disease was complicated by proteinuria, hypoalbuminaemia, and amyloidosis, the last being confirmed by rectal biopsy.

\section{Discussion}

The clinical picture in these three cases of ankylosing spondylitis with amyloid disease had some characteristic features in common. All the patients suffered from a severe systemic disease with poor general condition, high erythrocyte sedimentation rate (with values above $100 \mathrm{~mm}$./ hr), and negative serological tests for rheumatoid disease. All had destructive changes in the sacro-iliac joints, one had syndesmophytes in the thoracic and lumbar spine, and one had typical bamboo spine. Involvement of large peripheral joints without marked cartilaginous or bony destruction occurred in all.

The appearance of proteinuria was the first clinical sign of amyloidosis. It was diagnosed after a period of 19,5 , and about 2 years from the onset of the basic disease. Proteinuria was accompanied by the amyloid nephrosis syndrome with hypoalbuminaemia, hypercholesterolaemia, and (in two cases) pitting oedema. There was no enlargement of the liver or spleen, the blood pressure remained normal, and the kidney size was radiologically normal. Creatinine clearance was normal in two and slightly diminished in one case.

The congo red test is very unreliable as an aid to the diagnosis of amyloid disease and the interpretation of the results is difficult. Histological examination is indispensable for a firm diagnosis. A kidney biopsy was performed in two of our cases and a rectal biopsy in one. According to Blum and Sohar (1962), rectal biopsy is only exceeded by renal biopsy as a means of obtaining positive results in amyloidosis. However, rectal biopsy is to be preferred because it is much easier to perform, painless, and practically devoid of danger. Therefore rectal biopsy seems to be the procedure of the future for diagnosing amyloidosis. The degree of amyloid deposits in the biopsy specimens was moderate in two of our cases and marked in the third.

The occurrence of amyloidosis as a complication of rheumatoid arthritis is well known (Teilum, 1952; Teilum and Lindahl, 1954; Reece and Reynolds, 1954; Missen and Taylor, 1956; Unger, Zuckerbrod, Beck, and Steele, 1948). The demonstration of amyloid disease in ankylosing spondylitis is a further common link between these two conditions and may be produced by a causative mechanism of the same nature. 


\section{Summary}

Three cases of ankylosing spondylitis complicated by amyloidosis are reported. All had very active systemic disease with simultaneous involvement of large peripheral joints, a very high erythrocyte sedimentation rate, negative serological tests for rheumatoid disease, proteinuria, and hypoalbuminaemia.

The presence of amyloidosis was confirmed by renal biopsy in two cases and rectal biopsy in the third.

\section{REFERENCES}

Blum, A., and Sohar, E. (1962). Lancet, 1, 721.

Halford, M. E. H., and Clark, C. J. (1957). Ann. rheum. Dis., 16, 460.

Missen, G. A. K., and Taylor, J. D. (1956). J. Path. Bact., 71, 179.

Reece, J. M., and Reynolds, T. B. (1954). Amer. J. med. Sci., 228, 554.

Teilum, G. (1952). Ann. rheum. Dis., 11, 119. and Lindahl, A. (1954). Acta med. scand., 149, 449.

Unger, P. U., Zuckerbrod, M., Beck, G. J., and Steele, J. M. (1948). Amer. J. med. Sci., 216, 61.

\section{Amyloïdose dans la spondylarthrite ankylosante}

\section{RÉSUMÉ}

On rapporte trois cas de spondylarthrite ankylosante compliqués d'amyloïdose. Dans tous ces cas la maladie générale était très active, avec l'implication simultanée de plusieurs grandes articulations périphériques, une vitesse de sédimentation érythrocytaire très élévée, des réactions sérologiques négatives pour la maladie rhumatismale, une protéinurie et une hypoalbuminémie.

La présence de l'amyloïdose fut confirmée par la biopsie rénale dans deux cas et par la biopsie rectale dans un cas.

\section{Amiloidosis en la espodilartritis anquilosante}

\section{SUMARIO}

Se relatan tres casos de espondilartritis anquilosante complicada de amiloidosis. En todos los casos la enfermedad general fué muy activa, con implicación simultánea de varias grandes articulaciones periféricas, velocidad de sedimentación eritrocitaria muy alta, reacciones serológicas negativas para la enfermedad reumatoide, proteinuria e hipoalbuminemia.

La presencia de amiloidosis fué confirmada por biopsias renales en dos casos y por biopsia rectal en uno. 